\title{
Molecular Monitoring of Wild-Type and Genetically Engineered Colletotrichum coccodes Biocontrol Strains In Planta
}

\author{
A. L. Dauch, B. Ahn, A. K. Watson, P. Seguin, and S. H. Jabaji-Hare, Department of Plant Science, Macdonald \\ Campus of McGill University, Sainte-Anne-de-Bellevue, Québec, H9X 3V9, Canada
}

\begin{abstract}
Dauch, A. L., Ahn, B., Watson, A. K., Seguin, P., and Jabaji-Hare, S. H. 2006. Molecular monitoring of wild-type and genetically engineered Colletotrichum coccodes biocontrol strains in planta. Plant Dis. 90:1504-1510.

Two strains of Colletotrichum coccodes, the wild type (DAOM 183088) and T-20a, engineered with the necrosis- and ethylene-inducing peptide (NEPI) gene for hypervirulence on velvetleaf (Abutilon theophrasti, Medik.), were monitored in planta for the first 2 weeks after infection. Real-time quantitative polymerase chain reaction (QPCR) was used to assess the extent of colonization of both strains on velvetleaf using SYBR Green chemistry. Quantification of both strains was successful as soon as the conidia were sprayed on the leaves and up to 14 days after infection. The increase in fungal DNA amounts corroborated with the appearance of necrotic lesions on velvetleaf leaves infected with the wild-type strain. The wild-type $C$. coccodes was more efficient at infecting velvetleaf than the transgenic T-20a strain. In addition, detection of host DNA allowed us to quantitatively monitor the decrease in plant DNA amounts in response to wild-type strain infection. Expression of the NEP1 transgene by conventional retrotranscription (RT)-PCR was absent from T-20a growing on either V8 agar or in planta, suggesting that the gene may be silenced. The application of QPCR to monitor fungal growth was proven to detect the target organisms in planta prior to the appearance of symptoms.
\end{abstract}

The genus Colletotrichum is one of the most important worldwide fungal pathogen that commonly is known as the anthracnose pathogen. Colletotrichum coccodes (Wallr.) Hughes, the anamorph of Glomerella (38), has been studied as a potential bioherbicide for the control of velvetleaf, Abutilon theophrasti Medik $(20,42)$. It can severely damage or kill velvetleaf when applied to young seedlings bearing only cotyledons or, at most, one true leaf (46); however, when applied at later growth stages, plants continue to grow after shedding their infected leaves. Increased virulence recently was achieved by transferring the necrosis- and ethyleneinducing peptide (NEPl) gene encoding a Fusarium oxysporum phytotoxic protein into the $C$. coccodes wild-type strain (DAOM 183088) (6,25). The resulting transgenic strain of $C$. coccodes, T-20a, was nine times more virulent than the wild-type against velvetleaf at the threetrue-leaf stage when applied as chopped mycelium (3). Despite this success, T-20a host range was not limited to velvetleaf, as

Corresponding author: S. H. Jabaji-Hare

E-mail: suha.jabaji-hare@mcgill.ca

GenBank accession numbers used in this study: AY 138969, AF036580, and AF448480.

Accepted for publication 11 July 2006.

DOI: 10.1094/PD-90-1504

(C) 2006 The American Phytopathological Society is the case of the wild-type strain, but was extended to include tobacco and tomato plants, causing 67 to $100 \%$ seedling mortality, respectively (3). A prerequisite for the release of wild-type or genetically engineered biological control agents is our ability to monitor them in the environment in order to evaluate their colonization success and to assess environmental risks. With this end in view, we recently have developed strain-specific polymerase chain reaction $(\mathrm{PCR})$ primers $(\mathrm{N} 5 \mathrm{Fi} / \mathrm{N} 5 \mathrm{Ri})$ for the detection of the wild-type $C$. coccodes (DAOM 183088) in planta and in deliberate-release field soils (13).

Some species of Colletotrichum are well known to exhibit hemibiotrophic life styles in which they establish themselves in host cells by eluding detection and forming associations with living cells, much like biotrophs. Later, during the infection process, they behave as necrotrophs, spreading rapidly and actively killing host cells (33). Examination of disease progression by quantifying the amount of fungal biomass, especially during the biotrophic phase of a pathogen, is not always easy, and most methods rely on the appearance of symptoms or quantification of fruiting structures $(31,32)$ and the quantification of sterols or chitin $(18,36)$. Other techniques for assessing fungal biomass include enzyme-linked immunosorbent assay, monitoring Betaglucuronidase or green fluorescent protein activity in interactions with microorganisms transformed with the bacterial UidA genes or the green fluorescent protein, respectively, as fungal biomass reporters in transformants $(2,11,21)$. The major drawback associated with these methods resides in the fact that plant factors can interfere with the measured parameter (39). Pathogen development often is monitored through scoring of disease symptoms; however, several studies have shown that development of symptoms does not always correlate with actual pathogen colonization. Therefore, it is important to assess pathogen growth rather than disease symptoms.

Real-time quantitative PCR (QPCR) is now widely used in the quantitative detection of pathogens due to its sensitivity, specificity, and efficiency as well as the freedom from post-PCR analysis steps (35). Recently, it has become the method of choice in plant pathology to monitor pathogen colonization through DNA quantification in plant tissue $(1,7,17,23,41)$. Currently, two common approaches of analyzing data from QPCR experiments are used: (i) absolute quantification is achieved by comparison of the unknown sample to a standard curve in which the threshold cycle $\left(\mathrm{C}_{\mathrm{T}}\right)$ numbers are plotted against starting fungal DNA quantities $(9,10)$, and (ii) relative quantification describes the change in $\mathrm{C}_{\mathrm{T}}$ number of an unknown sample in relation to the $\mathrm{C}_{\mathrm{T}}$ of a reference such as an untreated control or a sample treated at time zero in a time course study (27).

Comparisons of the $C$. coccodes wildtype (DAOM 183088) and the transgenic strain T-20a growth kinetics, and monitoring their infection spanning the biotrophic and necrotrophic growth stages, have not yet been attempted. The objective of this study was to use QPCR to monitor the molecular growth kinetics of both strains in planta when applied as conidia at various times following velvetleaf infections. We used the strain-specific primers $\mathrm{N} 5 \mathrm{Fi} / \mathrm{N} 5 \mathrm{Ri}$ and primers targeting the NEP1 gene (Nep1693/1893) to quantify the growth of wild-type and transgenic T20a C. coccodes, respectively, on velvetleaf. An additional primer set was developed to quantify the endogenous HPPD plant gene in response to $C$. coccodes infection.

\section{MATERIALS AND METHODS}

Mycelia and conidia preparation. $C$. coccodes velvetleaf wild-type strain (DAOM 183088) was obtained from the 
Biosystematics Research Institute (Ottawa, ON, Canada). C. coccodes transgenic strain (T-20a), engineered to express the NEP1 gene encoding the phytotoxin protein Nep1 (3), was graciously provided by J. Gressel (Weizmann Institute, Israel). Both strains were grown on potato dextrose agar (PDA; Becton Dickinson Microbiology Systems, Sparks, MD) for 1 week at $28^{\circ} \mathrm{C}$ in the dark.

For DNA extraction, five agar plugs (5 $\mathrm{mm}$ in diameter) were transferred into 75 $\mathrm{ml}$ of potato dextrose broth (PDB; Becton Dickinson Microbiology Systems) and incubated at room temperature for 12 days under low agitation (100 rpm). Mycelial mats were collected by filtration using Whatman no.1 filter paper, freeze dried for 2 days, and ground with liquid nitrogen. Powdered mycelia were conserved at $-20^{\circ} \mathrm{C}$ until DNA extraction. For RNA extraction, mycelium of T-20a C. coccodes was grown in triplicate petri plates for a week on V8 agar medium (29) overlaid with a nylon membrane (500 PUT, UCB, North Augusta, SC). Fungal mycelium was scraped off the membrane and immediately flash frozen in liquid $\mathrm{N}$.

Conidia for velvetleaf inoculation were produced on modified Richard medium (MRM; 14). Five agar plugs taken from 1week-old PDA cultures of either the wild type or T-20a were inoculated in $600 \mathrm{ml}$ of MRM and incubated at $24^{\circ} \mathrm{C}$ on a rotary shaker $(200 \mathrm{rpm})$ for 7 days. The conidia were harvested through filtration and centrifuged at $4^{\circ} \mathrm{C}$ for $10 \mathrm{~min}$ at $6,000 \times g$, the conidial pellet was resuspended in double distilled $\mathrm{H}_{2} \mathrm{O}\left(\mathrm{ddH}_{2} \mathrm{O}\right)$, and conidial suspensions were adjusted to the desired concentrations in $\mathrm{ddH}_{2} \mathrm{O}$ using a hemacytometer.

Plant growth conditions and inoculation. A. theophrasti seed were pregerminated in 100 -by-15 mm petri dishes on Whatman no. 1 papers moistened with $4 \mathrm{ml}$ of distilled water. The petri dishes were stored for 3 days at room temperature. Two pre-germinated seed were planted in a Cone-tainer (Stuewe and Sons, Corvallis, OR) of 164-ml capacity. Prior to use, the Cone-tainers were surface sterilized for $45 \mathrm{~min}$ in $3 \%$ solution of sodium hypochlorite, rinsed with distilled water, and filled with moist nonsterile Promix (Promix Inc., Rivière du Loup, QC, Canada). The Cone-tainers were placed on racks in growth chambers. Conditions were adjusted to 24 and $18^{\circ} \mathrm{C}$ for 10 and $14 \mathrm{~h}$, day and night, respectively, with a light intensity of $300 \mu \mathrm{M} / \mathrm{m}^{2}$. One week after seeding, plants were thinned so as to leave one seedling per Cone-tainer. Plants were watered as needed and fertilized every 2 weeks after the initial seeding with a 20-ml (3 g/liter) solution of 20:20:20 (N:P:K) until they were 4 weeks old (fiveleaf stage). Inoculation of velvetleaf plants was performed in a spray chamber ( $\mathrm{Re}$ search Instrument MFG. Co. Ltd., Guelph,
ON, Canada) to ensure uniform coverage of the leaves. The inoculated plants were placed in a dew chamber $(90 \%$ humidity, $24^{\circ} \mathrm{C}$ ) for $18 \mathrm{~h}$ to maximize fungal infection. There were 144 plants, out of which one-third received $\mathrm{ddH}_{2} \mathrm{O}$ (control treatment), and the remaining were similarly inoculated with a $10^{6}$ conidia/ml suspension $\left(50 \mathrm{ml} / \mathrm{m}^{2}\right)$ of either wild-type or T20a $C$. coccodes. Plants were returned to the growth chamber and randomized following a randomized complete block design. Rating for disease development was done on 12 plants/fungal strain (12 replicates) every $24 \mathrm{~h}$ until 14 days after infection (DAI). Plants were scored for disease using the following scale: $0=$ no infection; $1=$ hypersensitive reaction on most leaves or necrotic lesions on some leaves; 2 = advanced necrotic lesions on most leaves; $3=$ severe infection on most leaves and some necrotic lesions on the stem, but plants are alive; and $4=$ complete death of plants. For DNA and RNA extractions, each experimental unit consisted of two leaves from two plants grown in separate Cone-tainers. There were four replicates per fungal strain per time point.

For the study of $C$. coccodes growth kinetics in planta (with real-time PCR), two third leaves were excised at the base of the petioles at six different time points (immediately after inoculation $=0$, and 1, 2, 5, 7, and $14 \mathrm{DAI}$ ) for DNA extractions and at 12 $\mathrm{h}$ and 7 DAI for RNA extractions. All leaf samples for DNA and RNA extractions were ground in liquid $\mathrm{N}$ with the addition of $0.5 \mathrm{~g}$ of $\mathrm{NaCl}$ and $0.33 \mathrm{~g}$ of polyvinylpolypyrrolidone (PVPP) per replicate to prevent the mucilaginous material from interfering in the nucleic acid extraction processes. A guanidine isothiocyanate base (RLT) buffer from the Qiagen RNeasy Plant Mini-Kit (Qiagen, Mississauga, ON, Canada) was immediately added to the samples used for RNA extraction as recommended by the manufacturer. All samples were kept at $-80^{\circ} \mathrm{C}$ prior to RNA and DNA extractions.

To compare DNA quantification accuracy and detection threshold of DNA extracted from inoculated velvetleaf to that extracted from pure conidia suspensions, $500 \mu \mathrm{l}$ of each serially diluted concentration of conidia $\left(2 \times 10^{3}, 2 \times 10^{4}, 2 \times 10^{5}, 2\right.$ $\times 10^{6}$, and $2 \times 10^{7}$ conidia $/ \mathrm{ml}$ of $\mathrm{ddH}_{2} \mathrm{O}$ ) of C. coccodes wild type were placed in 2-ml screw-capped Eppendorf tubes (four replicates). Xymotech silica beads (20 mg; Xymotech Biosystems, Inc., Mont-Royal, QC, Canada) were added to each tube and conidia were violently disrupted in a FastPrep apparatus (Thermo Savant, Holbrook, NY) set at speed level 4 for $20 \mathrm{~s}$. Samples were frozen immediately at $-80^{\circ} \mathrm{C}$ prior to DNA extraction. For the plant DNA detection threshold, serial dilutions of the wild type at $10^{5}, 10^{6}, 10^{7}$, and $10^{8}$ conidia/ml were sprayed on the plants (four replicates/serial dilution) using the above- described conditions $(50 \mathrm{ml}$ of conidial suspension $/ \mathrm{m}^{2}$ ). Two third leaves were excised, immediately dipped in liquid nitrogen, and stored at $-80^{\circ} \mathrm{C}$ prior to DNA extraction.

Nucleic acid extractions and cDNA retro-transcription. Total fungal genomic DNA (gDNA) was isolated from $20 \mathrm{mg}$ of freeze-dried mycelium as previously described (13). Total gDNA from velvetleaf leaves and conidia from the wild-type strain were extracted using the Qiagen DNeasy Plant Mini-Kit (Qiagen) following the manufacturer's protocol, except that all pipetting steps were carried out on ice, centrifugation steps at $4^{\circ} \mathrm{C}$, and an additional washing step was performed. DNA was eluted in 200 and $100 \mu$ l of Qiagen buffer for velvetleaf leaves and $C$. coccodes conidia, respectively. DNA extracts from all biological material were quantitatively and qualitatively estimated by spectrophotometry. Samples giving absorbance $\left(A_{260} / A_{280}\right)$ ratios below 1.7 or above 2.0 were rejected. All extracts were run on $1 \%$ agarose gels $(1 \times$ Tris-acetate EDTA [TAE]) to verify the absence of DNA degradation.

Fungal RNA was isolated from mycelia using the Qiagen RNeasy Plant Mini-Kit following the manufacturer's recommendations. To examine the expression of the NEP1 gene during T-20a interaction with velvetleaf, total RNA was extracted from inoculated velvetleaf leaves using the same Qiagen kit with the following modifications: two lilac (Qiagen filtration) columns were loaded with $700 \mu$ of RLT buffer resuspended in plant powder, and their precipitate was pooled in a single pink column for each sample unit. RNA extracts were treated with TURBO DNase (Ambion Inc., Austin, TX) to remove any potential DNA contaminant, and checked for the absence of DNA contamination in conventional PCR using conditions described for internal transcribed spacer (ITS) primer amplification (Table 1). The reaction consisted of $2 \mu \mathrm{l}$ of RNA extract as a template and $2 \mu \mathrm{l}$ of velvetleaf gDNA $(10 \mathrm{ng} / \mu \mathrm{l})$ as a positive control, respectively. DNA-free RNA (500 ng) was loaded on $1.2 \%$ agarose denaturing formaldehyde gels to check the integrity of the isolated nucleic acids. cDNA were generated from $500 \mathrm{ng}$ of RNA with the Omniscript RT and QuantiTect Rev. Transcription kits (Qiagen).

PCR primer sets. Primers used for the quantification of $C$. coccodes wild type, T20a, and velvetleaf are presented in Table 1. N5Fi/N5Ri (SCAR) was previously developed as a strain-specific primer set for $C$. coccodes (velvetleaf strains; 13). It amplifies part of an anonymous DNA sequence $(380 \mathrm{bp}$; accession number AF448480) and is used in this study to quantify $C$. coccodes wild-type DNA. The Nep1F/R primer set (Table 1) flanks the NEP1 gene (accession number AF036580) and is used to detect $C$. coccodes T-20a 
DNA and cDNA. It amplifies a putative product of $341 \mathrm{bp}$ in conventional PCR assays. However, because we could not optimize them in real-time PCR assays, new primers (Nep1693/1893) were designed (anneal on base 1,693 and 1,893 of the NEP1 gene) for T-20a quantification. Nep1693/1893 should amplify a 200-bp amplicon from both T-20a DNA and cDNA. The primer set HPPDF/R was used to quantify the 4-hydroxyphenylpyruvate dioxygenase gene (HPPD; accession number AY 138969) from velvetleaf. The HPPD gene encodes a product that is involved in the degradation of aromatic amino acids (40). As a reporter of plant health and similar to other plant health reporter genes $(17,23,45)$, HPPD DNA quantification was used to evaluate the effects of fungal infection on the amounts of quantifiable plant DNA. Universal primers were used in conventional PCR to check for the presence of amplifiable DNA; ITS4/5 primers flank the ITS regions (1 and 2) of plants and fungi (43). These primers are expected to amplify DNA from velvetleaf, and wild-type and T20a $C$. coccodes (Table 1). The histone 4 primers, H4-1a/-1b (Table 1), target the ascomycete histone 4 gene (19) and were used to check the integrity of the cDNA synthesized from RNA originated from T20a mycelia and from T-20a-infected velvetleaf plants, and to exclude falsenegative results obtained with NEPI genespecific primers. They amplify DNA fragments of 250 and 200 bp from T-20a $C$. coccodes gDNA and cDNA, respectively.

Conventional PCR conditions. Conventional PCR was performed in an Applied Biosystems 9600 (Foster City, CA) as follows. The reaction mix $(25 \mu \mathrm{l})$ consisted of $2 \mu \mathrm{l}$ of DNA template, $0.2 \mu \mathrm{M}$ each of the primers, $2.5 \mu \mathrm{l}$ of $10 \times$ buffer
(200 mM Tris- $\mathrm{HCl}, \mathrm{pH} 8.4$, and $500 \mathrm{mM}$ $\mathrm{KCl}$ ), $0.5 \mathrm{U}$ of $\mathrm{Taq}$ polymerase (Invitrogen, Burlington, ON, Canada), and 200 $\mathrm{nM}$ each dNTP (Invitrogen, Burlington, ON, Canada). Reactions were prepared on ice and cycled for $3 \mathrm{~min}$ at $94^{\circ} \mathrm{C} ; 30$ cycles of $1 \mathrm{~min}$ at $94^{\circ} \mathrm{C}$ and $1 \mathrm{~min}$ at $62,59,60$, 58 , or $68^{\circ} \mathrm{C}$ for $\mathrm{N} 5 \mathrm{Fi} / \mathrm{N} 5 \mathrm{Ri}$, Nep1F/R, HPPDF/R, ITS4/5, and H4-1a/-1b, respectively, and $1 \mathrm{~min}$ at $72^{\circ} \mathrm{C}$; and a final extension step at $72^{\circ} \mathrm{C}$ for $10 \mathrm{~min}$. A negative control containing $\mathrm{ddH}_{2} \mathrm{O}$ was included in each run. PCR products were resolved on $1 \%$ agarose gels $(1 \times$ TAE). The absence of satisfactory spectrophotometry readings and electrophoresis of purified DNA, or the absence of amplified products during the ITS-PCR steps, was sufficient to reject the sample and DNA was re-extracted from the original tissue.

Conventional retro-transcription PCR conditions. Retro-transcription (RT)-PCR was performed to check (i) the quality of the synthesised cDNA with histone 4 (H4$1 \mathrm{a} /-1 \mathrm{~b}$ ) primers (Table 1) and (ii) the presence or absence of NEPl gene expression with the Nep1F/R primers (Table 1) using conditions described earlier. The cDNA template was used as such or diluted in $\mathrm{ddH}_{2} \mathrm{O}(2-, 5-, 10-, 50-$, or 100-fold) and the positive control consisted of $2 \mu \mathrm{l}$ of T$20 \mathrm{a} C$. coccodes gDNA (10 ng/ $\mu \mathrm{l})$.

Absolute DNA quantification by realtime PCR. Absolute real-time PCR quantification was conducted to determine the quantities of $C$. coccodes strains in velvetleaf samples. External standards for $C$. coccodes DNA quantification consisted of six serially diluted DNA of T-20a or wildtype gDNA ( 5 and $0.5 \mathrm{ng} / \mu \mathrm{l} ; 50,5$, and 0.5 $\mathrm{pg} / \mu \mathrm{l}$; and $50 \mathrm{fg} / \mu \mathrm{l})$. Velvetleaf DNA standards consisted of six serial dilutions $(0.5$ $\mathrm{pg} / \mu \mathrm{l} ; 50,5$, and $0.5 \mathrm{fg} / \mu \mathrm{l}$; and 50 ag and 5 $\mathrm{ag} / \mu \mathrm{l})$ of the purified HHPD amplicon obtained with the HPPD primer set using Qiagen PCR purification kit (Qiagen). All standards were prepared in $10 \mathrm{mM}$ Tris$\mathrm{HCl}(\mathrm{pH} \mathrm{7.4)}$ and included in triplicates in each real-time PCR quantification run to construct a standard curve and calculate quantities of fungal or plant DNA in the unknown samples. Quantification algorithms used for the calculation of unknown DNA amounts included the amplification threshold, the adaptive baseline, and the moving average $(\mathrm{Mx} 300 \mathrm{P}$ real-time PCR system software, version 2.0; Stratagene La Jolla, CA). Standard curves were constructed from triplicate standards using their $\mathrm{C}_{\mathrm{T}}$ numbers, PCR cycle numbers at which the fluorescence of the sample exceeds the background fluorescence, and the known starting DNA amounts. Unknown DNA amounts from the samples were back calculated using the standard curves.

Each real-time PCR reaction mix consisted of $10 \mu \mathrm{l}$ of Stratagene Brilliant SYBR Green master mix (Stratagene), $1.25 \mu \mathrm{l}$ of each primer $(2 \mu \mathrm{M}), 2.2 \mu \mathrm{l}$ of sterile $\mathrm{ddH}_{2} \mathrm{O}, 0.3 \mu \mathrm{l}$ of ROX reference dye (Stratagene), and $5 \mu \mathrm{l}$ of $1 / 10$ th diluted (wild-type $C$. coccodes and velvetleaf DNA quantifications) or $4 \mu \mathrm{l}$ of $1 / 10$ th diluted DNA template (T-20a C. coccodes DNA quantification). Thermocycling was performed with an initial denaturation at $95^{\circ} \mathrm{C}(10 \mathrm{~min})$, followed by 40 to 50 cycles at $95^{\circ} \mathrm{C}(30 \mathrm{~s}), 63^{\circ} \mathrm{C}(\mathrm{N} 5 \mathrm{Fi} / \mathrm{N} 5 \mathrm{Ri}), 61^{\circ} \mathrm{C}$ (Nep1693/1893), or $64^{\circ} \mathrm{C}(\mathrm{HPPDF} / \mathrm{R})(1$ $\mathrm{min})$, and $72^{\circ} \mathrm{C}(30 \mathrm{~s})\left(2.5^{\circ} \mathrm{C} / \mathrm{s}\right)$. Finally, a melting curve was generated by programming the thermocycler to reach $95^{\circ} \mathrm{C}(60$ $\mathrm{s}), 55^{\circ} \mathrm{C}(30 \mathrm{~s})\left(2.5^{\circ} \mathrm{C} / \mathrm{s}\right)$, and $95^{\circ} \mathrm{C}(0 \mathrm{~s})$ $\left(0.1^{\circ} \mathrm{C} / \mathrm{s}\right)$. Each run included a negative control and was repeated twice on two different days (two technical replicates).

To rule out any interference of PCR in-

Table 1. Polymerase chain reaction (PCR) primer characteristics

\begin{tabular}{|c|c|c|c|c|c|c|c|c|}
\hline \multirow[b]{3}{*}{ DNA target ${ }^{\mathrm{s}}$} & \multirow[b]{3}{*}{ Primer } & \multicolumn{3}{|c|}{ Amplification $^{r}$} & \multirow[b]{3}{*}{ Appl $^{t}$} & \multirow[b]{3}{*}{ Sequence $\left(5^{\prime}\right.$ to $\left.3^{\prime}\right)$} & \multirow[b]{3}{*}{$\operatorname{Tm}\left({ }^{\circ} \mathbf{C}\right)^{\mathbf{u}}$} & \multirow[b]{3}{*}{ Amplicon size (bp) } \\
\hline & & \multicolumn{2}{|c|}{ C. coccodes } & \multirow[b]{2}{*}{ Vel } & & & & \\
\hline & & Wild & T-20a & & & & & \\
\hline \multirow[t]{2}{*}{ C. coccodes SCAR (anon) } & $\mathrm{N} 5 \mathrm{Fi}^{\mathrm{v}}$ & + & + & - & $C \& Q$ & AATGGCGTTCATGAAGGTAG & 62 & 380 \\
\hline & $\mathrm{N} 5 \mathrm{Ri}^{\mathrm{v}}$ & & & & & ATCTCAATGAAGTACGTCGC & 62 & \\
\hline \multirow[t]{2}{*}{ C. coccodes $N E P 1$ gene } & Nep1Fw & - & + & - & $\mathrm{C}$ & CGGCAGCAGCGTAGAGGGTAG & 70 & 341 (DNA and cDNA) \\
\hline & Nep1R ${ }^{\mathrm{w}}$ & & & & & CCGACGGTTGTCAGCCATACAC & 62 & \\
\hline \multirow[t]{2}{*}{ C. coccodes NEP1 gene } & Nep1693 & - & + & - & Q & ССТCTTCTCCACATTGCCGA & 62 & 200 (DNA and cDNA) \\
\hline & Nep1893 & & & & & GCGGCACGAGCATATGTCT & 60 & \\
\hline \multirow[t]{2}{*}{ Velvetleaf HPPD gene } & $\mathrm{HPPDF}^{\mathrm{x}}$ & - & - & + & $C \& Q$ & GCTGCCTGTCGTTTCTCGTG & 64 & 155 \\
\hline & $\mathrm{HPPDR}^{\mathrm{x}}$ & & & & & TGGGAAAGAGCGATGGAAGG & 62 & \\
\hline \multirow[t]{2}{*}{ ITS 1 and 2} & ITS4 ${ }^{y}$ & + & + & + & $\mathrm{C}$ & TCCTCCGCTTATTGATATGC & 58 & $\approx 600($ C. coccodes $)$ \\
\hline & ITS5 $^{y}$ & & & & & GGAAGTAAAAGTCGTAACAAGG & 63 & $\approx 800$ (velvetleaf) \\
\hline \multirow[t]{2}{*}{ Histone 4 gene of ascomycetes } & $\mathrm{H} 4-1 \mathrm{a}^{\mathrm{z}}$ & + & + & - & $\mathrm{C}$ & GCTATCCGCCGTCTCGCT & 60 & $\approx 250(\mathrm{gDNA})$ \\
\hline & $\mathrm{H} 4-1 \mathrm{~b}^{\mathrm{z}}$ & & & & & GGTACGGCCCTGGCGCTT & 62 & $\approx 200(\mathrm{cDNA})$ \\
\hline
\end{tabular}

${ }^{\mathrm{r}}$ Differential PCR amplification on Colletotrichum coccodes strains (wild = wild type) and velvetleaf (Vel).

${ }^{\mathrm{s}} \mathrm{SCAR}=\mathrm{N} 5 \mathrm{Fi} / \mathrm{N} 5 \mathrm{Ri}$, anon. $=$ anonymous sequence, and ITS $=$ internal transcribed spacer.

${ }^{t}$ Application: $\mathrm{C}=$ conventional $\mathrm{PCR}$ and $\mathrm{Q}=$ quantitative real-time $\mathrm{PCR}$.

u $\mathrm{Tm}=$ temperature.

${ }^{v}$ Dauch et al. (13).

${ }^{\mathrm{w}}$ Amsellem et al. (3).

${ }^{x}$ Primers amplifying part of the 4-hydroxyphenylpyruvate dioxygenase gene of Abutilon theophrasti (accession number: AY138969).

${ }^{\mathrm{y}}$ White et al. (43).

${ }^{\text {z }}$ Glass and Donaldson (19). 
hibitors, a preliminary test was run to quantify the amounts of wild-type $C$. coccodes from five randomly selected plant DNA extracts originating from the growth kinetics DNA quantification experiment. DNA extracts were run in real-time PCR with triplicate standards to quantify the amounts of $C$. coccodes DNA starting from either 1/5th, 1/10th, 1/20th, 1/100th, or nondiluted DNA extracts. By calculating the amounts of target DNA and correcting for the dilution factor, a 1/10th dilution was found optimal for reliable quantification from all samples.

Post-PCR analyses. Amplification products from every PCR run were resolved on $1 \%$ electrophoresis agarose gels in 1× TAE buffer. A 100-bp DNA Ladder (Invitrogen) was used as a molecular weight ladder. Gels were stained with ethidium bromide and images were recorded by the gel print 2000i documentation system (BIOCAN Scientific, Mississauga, ON, Canada).

A

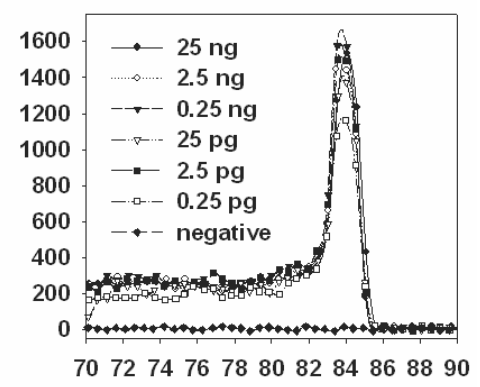

B

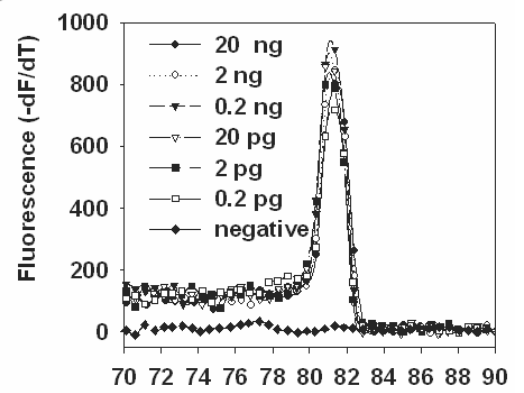

C

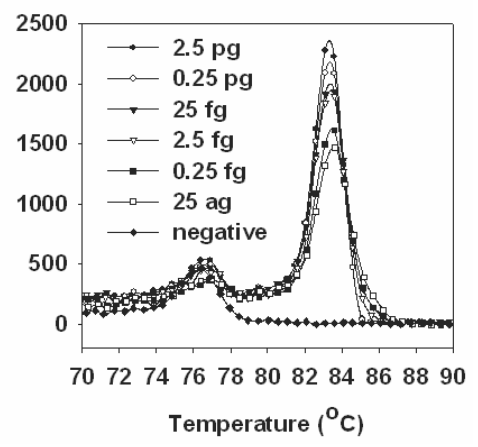

Fig. 1. Real-time polymerase chain reaction melting peaks for the quantification of $\mathbf{A}$, wildtype and B, T-20a Colletotrichum coccodes and C, velvetleaf DNA.
Statistical analysis. HPPD and C. coccodes DNA quantification data were analyzed by the Statistical Analysis System (SAS 8; SAS Institute, Cary, NC) using the analysis of variance procedure. Treatment means comparisons in each experiment were made using the least significant difference test at $P<0.05$ level.

\section{RESULTS}

Specificity and sensitivity. SYBR Green real-time PCR assays were developed for the quantification of two C. coccodes strains and their host plant velvetleaf DNA. Using their respective primers sets, gDNA from $C$. coccodes wild type and T20a showed single expected amplicons of 380 and $200 \mathrm{bp}$, respectively, as determined by either melting curve analysis (melting temperature $=83.8$ and $81.2^{\circ} \mathrm{C}$, respectively; Fig. 1A and $\mathrm{B}$ ) or agarose gel electrophoresis (Fig. 2, lanes 2 and 9). The HPPD primers also detected a single DNA fragment of $155 \mathrm{bp}$ (Fig. 2, lane 7) corresponding to a specific melting temperature

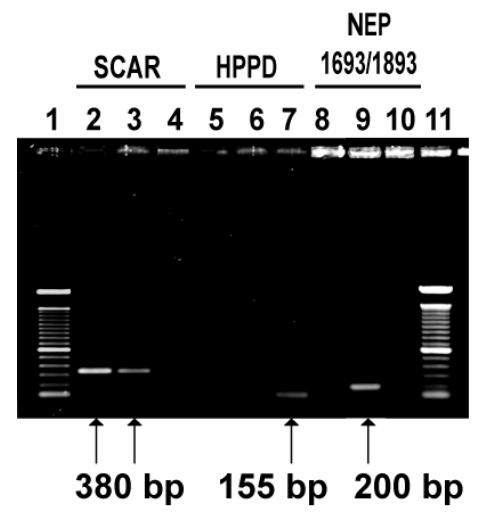

Fig. 2. Polymerase chain reaction gel electrophoresis showing specificities of the primers SCAR (lanes 2-4), HPPDF/HPPDR (lanes 5-7), and Nep1693/1893 (lanes 8-10) on wild-type Colletotrichum coccodes genomic (g)DNA (lanes 2, 5, and 8), T-20a C. coccodes gDNA (lanes 3, 6, and 9), and velvetleaf gDNA (lanes 4, 7, 10); lanes 1 and 11 contain a 100-bp ladder.

A

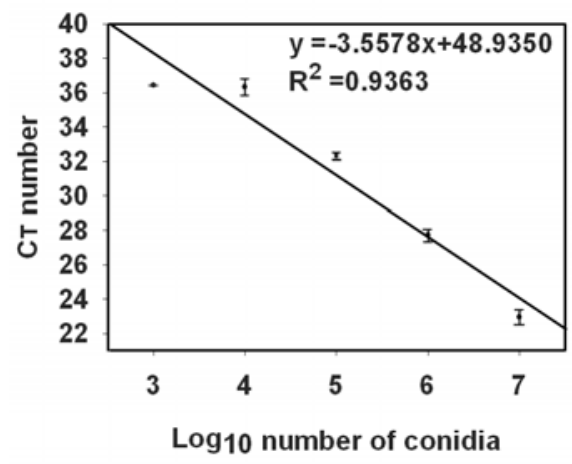

of $83.6^{\circ} \mathrm{C}$ (Fig. 1C) from velvetleaf DNA but not from fungal DNA (Fig. 2, lanes 5 and 6). A linear regression relation between logarithm of starting DNA quantities and PCR $\mathrm{C}_{\mathrm{T}}$ numbers over the range of DNA concentrations was established (data not shown). For each of the three target organisms studied, the regression correlation coefficient $\left(R^{2}\right)$ of detection exceeded 0.996 over six orders of magnitude, indicating high linearity. Depending on the target organism, as low as $2.5 \times 10^{-4} \mathrm{ng}$ of DNA for wild-type $C$. coccodes, $2.0 \times 10^{-4}$ ng of DNA $C$. coccodes T-20a, and $2.5 \times$ $10^{-8} \mathrm{ng}$ of DNA for velvetleaf could be quantified, the lowest starting DNA quantities examined. Amplification plots were highly reproducible between triplicate samples (data not shown) and fluorescence data from negative controls containing no templates always remained below the detection threshold (data not shown).

DNA extraction accuracy and reproducibility. Experiments were conducted to evaluate the accuracy and reproducibility of the DNA extraction method combined with real-time PCR quantification of wild-type $C$. coccodes using two approaches: DNA was extracted and then quantified from (i) pure serial dilutions of wild-type $C$. coccodes conidia and (ii) velvetleaf plants sprayed with serial dilutions of wild-type $C$. coccodes conidia. Both approaches resulted in a good correlation between the amounts of $C$. coccodes DNA quantified and the amounts of target organism initially present, whether in pure stand (Fig. $3 \mathrm{~A} ; R^{2}=0.9363$ ) or detected on the surface of velvetleaf (Fig. $3 \mathrm{~B} ; R^{2}=0.9891$ ) over five and four orders of magnitude, respectively. Starting from a pure stand of $C$. coccodes conidia, the assay was able to reproducibly detect as little as 50 conidia/reaction, the lowest conidial concentration examined (Fig. $3 \mathrm{~A})$. By extrapolation, the amount of $C$. coccodes DNA/conidium could be estimated to be $2.6 \times 10^{-6} \mathrm{ng}$ (data not shown).

Fig. 3. Relationship between cycle threshold $\left(\mathrm{C}_{\mathrm{T}}\right)$ numbers quantified by real-time polymerase chain reaction (PCR) and wild-type Colletotrichum coccodes conidia numbers $\mathbf{A}$, in a pure stand and $\mathbf{B}$, sprayed on velvetleaf leaves. The means (four replicates per conidial concentration) are $\mathrm{C}_{\mathrm{T}}$ numbers \pm standard errors as quantified by real-time PCR with SCAR primers. 
Monitoring $C$. coccodes during velvetleaf infection. At each time point and spanning the first 5 DAI, the average amount of DNA (6 pg per $0.1 \mathrm{~g}$ of leaf tissue) detected from both wild-type and T20a $C$. coccodes strains was not significantly different $(P>0.05)$ from each other (Fig. 4A). Over the same time period, few necrotic lesions started to develop on wildtype-infected leaves only and these became clearly discernable at 7 DAI (Fig. 4B), the time at which the amount of wild-type DNA compared with T-20a DNA significantly $(P<0.01)$ increased by sevenfold (Fig. 4A). No apparent symptoms were observed on velvetleaf infected with T-20a (Fig. 4B). By day 14, the amount of wildtype DNA detected increased by ninefold

A

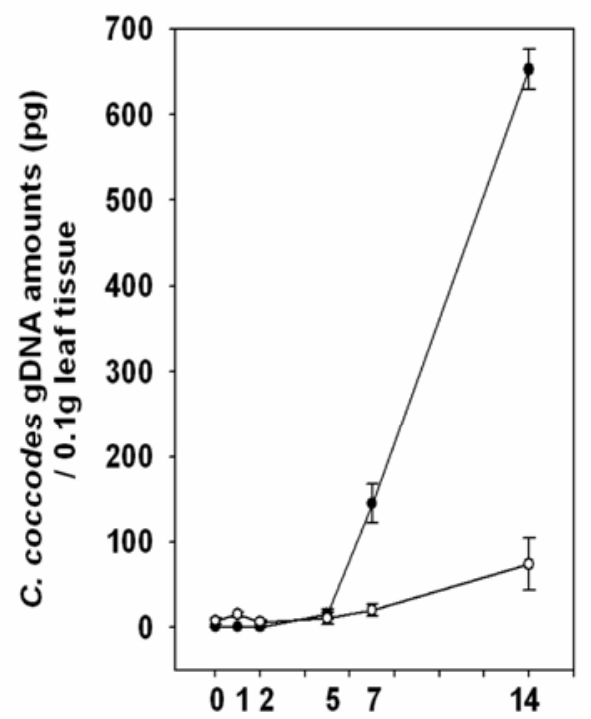

Days after infection (DAI)

C

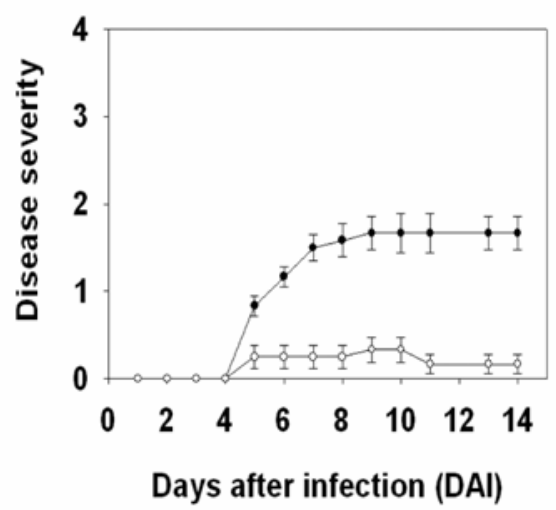

Fig. 4. Wild-type and T-20a Colletotrichum coccodes time-course infection on velvetleaf 0 to 14 days after infection (DAI). A, Fungal DNA quantification; $\bigcirc$ = wild-type and $\bigcirc=\mathrm{T}-20 \mathrm{a}$ C. coccodes. The numbers are mean values of four replicates per time-point per treatment \pm standard errors as quantified by real-time polymerase chain reaction with SCAR and Nep1693/1893 primers, respectively. B, Photographs of velvetleaf leaves infected and mock treated 7 and 14 DAI. C, Disease severity assessment performed on entire plants from 1 to 14 DAI on $O=$ wild-type and $\bigcirc=\mathrm{T}-20 \mathrm{a} C$. coccodes-infected plants. Disease scores represent means of 12 replicates per time-point per treatment (see Materials and Methods).
(653 pg per $0.1 \mathrm{~g}$ of leaf tissue), being statistically different $(P<0.05)$ from the amount of T-20a DNA (74 pg per $0.1 \mathrm{~g}$ of leaf tissue), with extensive necrotic lesions developed on all leaves to such an extent that only two biological replicates could be salvaged for DNA extraction (Fig. 4B). At the same day period, only a few lesions appeared on the foliage of velvetleaf infected with the transgenic strain (Fig. 4B).

The alteration in velvetleaf DNA mass in response to wild-type and T-20a $C$. coccodes infections was monitored using the primer set HPPD. Compared with the control treatment, the first apparent and significant $(P<0.001)$ decrease in velvetleaf DNA in response to the wild-type strain was detected 7 DAI, followed by a sub-

B

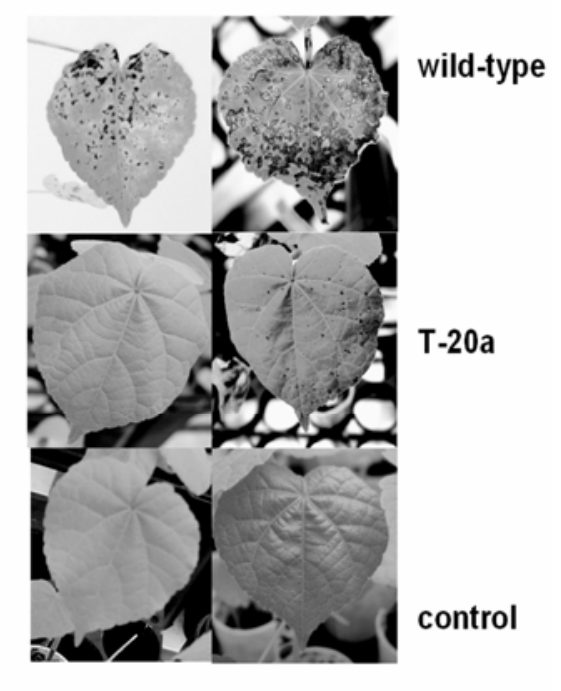

7 DAl 14 DAI stantial drop, reaching a low DNA amount of $0.36 \mathrm{pg}$ per $0.1 \mathrm{~g}$ of leaf tissue by day 14 , compared with the transgenic strain treatment and the uninfected control. In contrast, velvetleaf DNA amounts in response to T-20a infection remained similar to those estimated from uninfected velvetleaf foliage (control) at 7 DAI, but significantly $(P<0.001)$ decreased by day 14 (Table 2). This decrease in DNA with T-20a infection was not as substantial as that observed with the wild-type strain treatment. Disease severity (Fig. 4C) on whole plants, infected with either the wild-type or T-20a strain, corroborated well with the DNA quantification data showing no severe infection when T-20a was inoculated on velvetleaf plants. All experiments were repeated at least twice with comparable results

Expression of the NEP1 gene in vitro and in planta. No NEP1 transcript was detected in RNA isolated from either pure mycelium of T-20a growing on V8 agar (Fig. 5A, lane 2) or from velvetleaf foliage inoculated with $\mathrm{T}-20 \mathrm{a}$ and harvested after 12 h (Fig. 5A, lane 3) or at 7 DAI (Fig. 5A, lane 4). However, the transcript encoding the ascomycete Histone 4 gene was detectable in all of the analyzed samples (Fig. $5 \mathrm{~B}$, lanes 2 to 4 ), not only confirming the good quality of the cDNA but also its successful amplification.

\section{DISCUSSION}

In this study, we report on the molecular monitoring of two $C$. coccodes biocontrol strains under controlled growth conditions together with the quantification of host plant DNA by real-time QPCR. All of the primer's specificities and efficiencies have been established and rigorously validated for the three different targets. Calibration experiments with external standards demonstrated a strong dependency of the $\mathrm{C}_{\mathrm{T}}$ numbers on the logarithm of starting DNA quantities over six orders of magnitude. Taken together, we demonstrate, as did other recent studies $(1,7,8)$, the utility of real-time QPCR for reliable and accurate assessment of pathogen growth on velvetleaf and for monitoring velvetleaf DNA in response to pathogen infections.

When applied on the surface of velvetleaf, the wild-type $C$. coccodes did not develop any necrotic lesions before 5 DAI, and its DNA, as measured by real-time QPCR did not increase. This demonstrates that, during the first 5 DAI, $C$. coccodes has a biotrophic stage of growth. The switch to the necrotrophic stage seemed to occur after 5 days, at which the appearance of necrotic lesions coincided with the onset of an exponential-like increase in growth in the leaf as determined by QPCR. These results clearly demonstrate the effectiveness of QPCR for monitoring the progress of $C$. coccodes strains in planta, not only during the biotrophic growth stage when velvetleaf is symptomless but also at later stages of disease development. 
Among the aspects we verified were the reliability and accuracy of our methodology for pathogen quantification. We have shown that dilution series of pathogen conidia can be quantified accurately and correlated with DNA amounts over a large concentration range in the absence or presence of the host using real-time PCR. We demonstrated that the presence of velvetleaf tissue did not interfere in the quantification of $C$. coccodes conidia, a prerequisite for in planta DNA quantification. The detection threshold of wild-type $C$. coccodes corresponded to 50 conidia per PCR reaction (in the absence of the host) or $10^{5}$ conidia $/ \mathrm{m}^{2}$ (50 $\mathrm{ml}$ of conidial suspen$\operatorname{sion} / \mathrm{m}^{2}$ ) of velvetleaf tissue (in the presence of the host), the lowest inoculum concentration examined. Another aspect we evaluated was the potential interference of PCR inhibitors originating from plants which are known to affect the efficiency of PCR amplification (44). We have shown that a 1/10th dilution level of extracted DNA was ideal to preclude any bias due to PCR inhibitors.

In this study, there was a slight and constant decrease of velvetleaf DNA over the course of $C$. coccodes infections. This observation reasonably can be accounted for by plant cell collapse during pathogen progression. Some studies dealing with plant pathogen DNA quantification have used an endogenous plant reference in order to normalize for the amount of material loaded in the PCR reaction $(17,23,45)$. This approach is feasible when comparing pathogenic strains of similar aggressiveness or host resistance $(7,23)$. In this study, we have chosen not to normalize the pathogen concentration to an endogenous plant gene because of the difference in aggressiveness between the two strains studied. Furthermore, because tissue necrosis caused by a pathogen infection can lead to plant cell collapse and decreased amounts of detectable host DNA, it can be anticipated that normalizing pathogen DNA amounts to the amounts of detectable host genes such as the velvetleaf HPPD gene can lead to an overestimation of pathogen biomass (16). As a solution to this problem, all leaf samples analyzed in this study were normalized to the tissue weight and the decrease in plant DNA amounts observed across time were considered a consequence of necrotic lesions rather than a consequence of the unequal PCR loading of the sample PCR reactions.

$\mathrm{T}-20 \mathrm{a} C$. coccodes strain was genetically engineered for increased virulence on velvetleaf by insertion of NEP1 (3), a gene that is thought to participate in the natural virulence of many Fusarium oxysporum strains (5) in nature. Amsellen et al. (3) recently showed that the Nep1 genetically transformed $C$. coccodes strain T-20a is more virulent than the wild type and attacks velvetleaf faster, causing extensive necrotic lesions and early seedling death. They also demonstrated that that Nep1 protein was expressed in planta as early as $24 \mathrm{~h}$ after plant inoculation (3). In addition to the results of this study, we have conducted several independent inoculation trials using either chopped mycelia of T20 a or T-29, another NEP1 genetically transformed strain of C. coccodes (3) (from J. Gressel) as an inoculum source instead of conidia on young velvetleaf plants. Each of these strains grew on the surface of velvetleaf, but few necrotic lesions developed on the foliage of velvetleaf even after 14 days of infection and, thus, were delayed compared with lesions produced by the wild-type $C$. coccodesinfected plants. These results corroborated well with the molecular monitoring of T$20 \mathrm{a}$ on velvetleaf when the fungus was applied as conidia. The discrepancy in our results with those of Amsellen et al. (3) are difficult to explain. We have used velvetleaf seed from different sources and conducted several experiments at the cotyledonary and later stages of development under variable growth conditions, and applied both strains as either chopped mycelia or conidia. Regardless of these conditions, we were not able to obtain good infectivity for the T-20a strain.

Studies involving the Phytophthora sojae-soybean pathosystem have shown that the transcripts naturally encoding a Nep1like protein in $P$. sojae could be detected only from $12 \mathrm{~h}$ post plant inoculation (34). In this study, we could not detect expression of the NEP1 transcript in T-20a mycelia or in planta at $12 \mathrm{~h}$ or 7 days after inoculation. This observation, combined with the inability of T-20a to cause disease

Table 2. Quantification of velvetleaf DNA during time-course infection by Colletotrichum coccodes

\begin{tabular}{lccc}
\hline & \multicolumn{2}{c}{ Plant DNA amounts in plants infected by ${\text { C. } \text { coccodes }^{\mathbf{y}}}$} & \\
\cline { 2 - 3 } DAI $^{\mathbf{z}}$ & Wild-type & T-20a & Control plants \\
\hline 0 & $2.03 \pm 0.32$ & $1.77 \pm 0.44$ & $1.91 \pm 0.24$ \\
1 & $1.26 \pm 0.36$ & $1.93 \pm 0.35$ & $1.76 \pm 0.11$ \\
2 & $1.25 \pm 0.18$ & $1.97 \pm 0.19$ & $1.91 \pm 0.23$ \\
5 & $1.22 \pm 0.30$ & $2.11 \pm 0.31$ & $2.16 \pm 0.35$ \\
7 & $1.12 \pm 0.43 \mathrm{a}$ & $1.80 \pm 0.18 \mathrm{~b}$ & $1.81 \pm 0.16 \mathrm{~b}$ \\
14 & $0.36 \pm 0.02 \mathrm{a}$ & $1.78 \pm 0.22 \mathrm{~b}$ & $2.15 \pm 0.24 \mathrm{c}$ \\
\hline
\end{tabular}

${ }^{\mathrm{y}}$ Data presented are mean amounts (pg of DNA) \pm standard error as quantified by real-time polymerase chain reaction with HPPD primers from four replicates per time-point per treatment. Means within a row followed by a different letter are significantly different $(P<0.05)$.

${ }^{z}$ Days after infection. on velvetleaf, may be due to gene rearrangement events that silenced the expression of the NEPl gene in this strain. Several other research groups have reported that transgene-induced gene silencing occurs in plants and fungi, acting either at the transcriptional or the post-transcriptionnal level as genome defense systems $(4,12,30,37)$. Interestingly, we were able to detect the expression of the fungal housekeeping gene $\mathrm{H} 4$ in the same tissue samples, which clearly indicates that the RT-PCR method was able to detect the activity of fungal genes. One can argue that the failure to detect $N E P 1$ gene expression in our samples may be due to low levels of NEP1 RNA copies that are below the detection threshold, although several cDNA dilutions (from 2- to 100-fold) were tested, generating similar results. This may hold true for infected velvetleaf samples assayed at $12 \mathrm{~h}$ but it is unlikely when one considers the absence of NEP1 expression 7 days after inoculation, the time at which T20a population had increased by threefold.

In addition to gene silencing, repeated subculturing of fungal strains on artificial media $(24,26)$ or storage methods of fun-
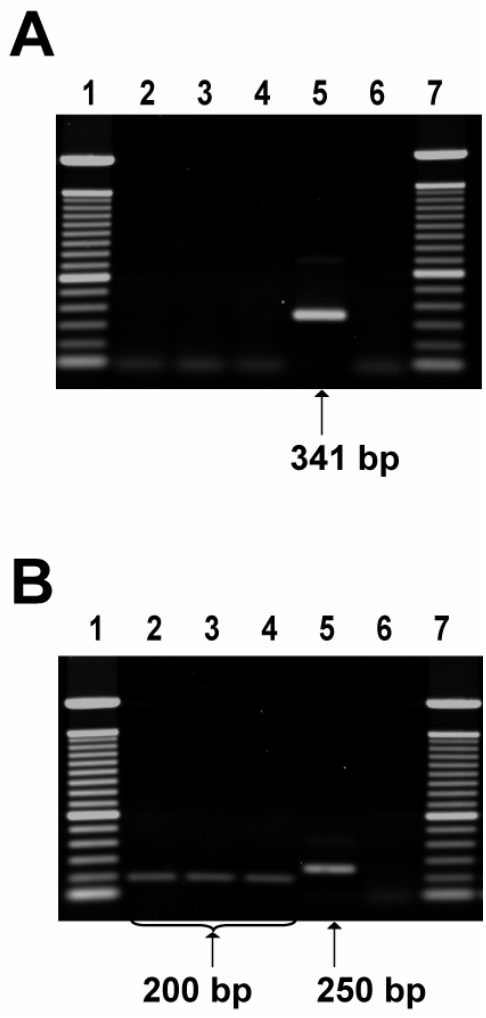

Fig. 5. Detection of $N E P 1$ gene expression in T20a Colletotrichum coccodes by retrotranscription polymerase chain reaction. The assay was performed with $\mathbf{A}, \mathrm{NEP} 1 \mathrm{~F} / \mathrm{R}$ primers (NEP1 gene) and $\mathbf{B}$, Histone 4 primers (housekeeping gene). cDNA templates from T-20a mycelium on V8 agar (lane 2) and T-20a-infected velvetleaf harvested at $12 \mathrm{~h}$ (lane 3 ) and 7 days (lane 4) after infection. Genomic (g)DNA template from T-20a $C$. coccodes (lane 5, positive control) and no-template control (lane 6, negative). Lanes 1 and 7 contain a 100-bp ladder. 
gal strains $(15,22)$ have been reported to contribute to instability in genomic integrity and loss in pathogenicity in fungal strains, resulting in genetic changes driven by genetic random drift and lack of selection for pathogenicity in the artificial laboratory environment (28). In line with these findings, both T-20a and T-29 transgenic C. coccodes strains have been revived from agar plugs stored under glycerol, and were subjected to serial vegetative transfers on artificial media without passing them through velvetleaf (J. Gressel, personal communication) prior to their use in the current study.

In the current work, a powerful tool has been developed to quantify accurately the growth kinetics of $C$. coccodes strains on the host weed velvetleaf and to assess their aggressiveness. The procedure enables a quantitative detection of the strains and overcomes the problem caused by $C$. coccodes's hemibiotrophic lifestyle. It will allow study of the invasion of the biocontrol agent even at early stages of velvetleaf infection, a prerequisite for the development of effective biocontrol strategies.

\section{ACKNOWLEDGMENTS}

Funding for this study was provided by a Natural Science and Engineering Research Council of Canada (NSERC) Discovery Grant to S. JabajiHare. We thank P. Cook for assistance in DNA extraction and manipulation.

\section{LITERATURE CITED}

1. Alkan, N., Gadkar, V., Coburn, J., Yarden, O., and Kapulnik, Y. 2004. Quantification of the arbuscular mycorrhizal fungus Glomus intraradices in host tissue using real-time polymerase chain reaction. New Phytol. 161:877-885.

2. Aly, R., Halpern, N., Rubin, B., Dor, E., Golan, S., and Hershenhorn, J. 2001. Biolistic transformation of Cercospora caricis, a specific pathogenic fungus of Cyperus rotundus. Mycol. Res. 105:150-152.

3. Amsellem, Z., Cohen, B. A., and Gressel, J. 2002. Engineering hypervirulence in a mycoherbicidal fungus for efficient weed control. Nat. Biotechnol. 20:1035-1039.

4. Armstrong, J. L., and Harris, D. L. 1993. Biased DNA integration in Colletotrichum gloesporioides f. sp. aeschynomene transformants with benomyl resistance. Phytopathology $83: 328-332$.

5. Bailey, B. A., Apel Birkhold, P. C., and Luster, D. G. 2002. Expression of NEP1 by Fusarium oxysporum f. sp. erythroxyli after gene replacement and overexpression using polyethylene glycol-mediated transformation. Phytopathology 92:833-841.

6. Bailey, B. A., Collins, R., and Anderson, J. D. 2000. Factors influencing the herbicidal activity of Nep1, a fungal protein that induces the hypersensitive response in Centaurea $\mathrm{macu}$ losa. Weed Sci. 48:776-785

7. Boyle, B., Hamelin, R. C., and Seguin, A. 2005. In vivo monitoring of obligate biotrophic pathogen growth by kinetic PCR. Appl. Environ. Microbiol. 71:1546-1552.

8. Brouwer, M., Lievens, B., Van Hemelrijck, W., Van den Ackerveken, G., Cammue, B. P. A., and Thomma, B. P. H. J. 2003. Quantification of disease progression of several microbial pathogens on Arabidopsis thaliana using realtime fluorescence PCR. FEMS Microbiol. Lett. 228:241-248.

9. Bustin, S. A. 2000. Absolute quantification of
mRNA using real-time reverse transcription polymerase chain reaction assays. J. Mol. Endocrinol. 25:169-193.

10. Bustin, S. A. 2002. Quantification of mRNA using real-time reverse transcription PCR (RTPCR): trends and problems. J. Mol. Endocrinol. 29:23-39.

11. Chen, N., Hsiang, T., and Goodwin, P. H. 2003. Use of green fluorescent protein to quantify the growth of Colletotrichum during infection of tobacco. J. Microbiol. Methods 53:113-122.

12. Cogoni, C., and Macino, G. 1997. Conservation of transgene-induced post-transcriptional gene silencing in plants and fungi. Trends Plant Sci. 2:438-443.

13. Dauch, A. L., Watson, A. K., and Jabaji-Hare, S. H. 2003. Detection of the biocontrol agent Colletotrichum coccodes (183088) from the target weed velvetleaf and from soil by strainspecific PCR markers. J. Microbiol. Methods 55:51-64.

14. DiTommaso, A., and Watson, A. K. 1995. Impact of a fungal pathogen, Colletotrichum coccodes on growth and competitive ability of Abutilon theophrasti. New Phytol. 131:51-60.

15. Elliott, M. L. 2005. Survival, growth and pathogenicity of Gaeumannomyces graminis var. graminis with different methods of longterm storage. Mycologia 97:901-907.

16. Gachon, C., and Saindrenan, P. 2004. Realtime PCR monitoring of fungal development in Arabidopsis thaliana infected by Alternaria brassicicola and Botrytis cinerea. Plant Physiol. Biochem. 42:367-371.

17. Gao, X., Jackson, T. A., Lambert, K. N., Li, S., Hartman, G. L., and Niblack, T. L. 2004. Detection and quantification of Fusarium solani f. sp. glycines in soybean roots with real-time quantitative polymerase chain reaction. Plant Dis. 88:1372-1380.

18. Gessner, M. O., and Schmitt, A. L. 1996. Use of solid-phase extraction to determine ergosterol concentrations in plant tissue colonized by fungi. Appl. Environ. Microbol. 62:415-419.

19. Glass, N. L., and Donaldson, G. C. 1995. Development of primer sets designed for use with the PCR to amplify conserved genes from filamentous ascomycetes. Appl. Environ. Microbol. 61:1323-1330.

20. Gotlieb, A. R., Watson, A. K., and Poirier, C. 1987. First report of Colletotrichum coccodes on velvetleaf. Plant Dis. 71:281.

21. Green, H., and Jensen, D. F. 1995. A tool for monitoring Trichoderma harzianum: II. The use of a GUS transformant for ecological studies in the rhizosphere. Phytopathology 85:1436-1440.

22. Hajek, A. E., Shimazu, M., and Humber, R. A. 1995. Instability in pathogenicity of Entomophaga maimaiga after long-term cryopreservation. Mycologia 87:483-489.

23. Hietala, A. M., Eikenes, M., Kvaalen, H., Solheim, H., and Fossdal, C. G. 2003. Multiplex real-time PCR for monitoring Heterobasidion annosum colonization in Norway spruce clones that differ in disease resistance. Appl. Environ. Microbiol. 69:4413-4420.

24. Hornby, D. 1998. Take-all Disease of Cereals: A Regional Perspective CAB International, Wallingford, UK

25. Jennings, J. C., Apel-Birkhold, P. C., Bailey, B. A., and Anderson, J. D. 2000. Induction of ethylene biosynthesis and necrosis in weed leaves by a Fusarium oxysporum protein. Weed Sci. 48:7-14.

26. Krokene, P., and Solheim, H. 2001. Loss of pathogenicity in the blue-stain fungus Ceratocystis polonica. Plant Pathol. 50:497-502.

27. Livak, K. J., and Schmittgen, T. D. 2001. Analysis of relative gene expression data using real-time quantitative PCR and the 2-(delta delta $\mathrm{C}_{\mathrm{T}}$ ) method. Methods 25:402-408.

28. Mackauer, M. 1976. Genetic problems in the production of biological control agents. Annu. Rev. Entomol. 21:369-385.

29. Martinez, C., Rioux, D., and Tweddell, R. J. 2004. Ultrastructure of the infection process of potato tuber by Helminthosporium solani, causal agent of potato silver scurf. Mycol. Res. 108:828-836.

30. Meyer, P. 1996. Repeat-induced gene silencing: common mechanisms in plants and fungi. Biol. Chem. Hoppe-Seyler 377:87-95.

31. Miller, S. A. 1996. Detecting propagules of plant pathogenic fungi. Pages 73-102 in: Advances in Botanical Research. Academic Press, London.

32. Pei, M. H., Ruiz, C., Harris, J., and Hunter, T. 2003. Quantitative inoculations of poplars with Melampsora larici-populina. Eur. J. Plant Pathol. 109:269-276.

33. Perfect, S. E., Hughes, H. B., O'Connell, R. J. and Green, J. R. 1999. Colletotrichum: a model genus for studies on pathology and fungal-plant interactions. Fungal Genet. Biol. 27:186-198.

34. Qutob, D., Kamoun, S., and Gijzen, M. 2002. Expression of a Phytophthora sojae necrosisinducing protein occurs during transition from biotrophy to necrotrophy. Plant J. 32:361-373.

35. Schena, L., Nigro, F., Ippolito, A., and Gallitelli, D. 2004. Real-time quantitative PCR: a new technology to detect and study phytopathogenic and antagonistic fungi. Eur. J. Plant Pathol. 110:893-908.

36. Schmitz, O., Danneberg, G., Hundeshagen, B., Klingner, A., and Bothe, H. 1991. Quantification of vesicular-arbuscular mycorrhiza by biochemical parameters. J. Plant Physiol. 139:106-114.

37. Selker, E. U. 1997. Epigenetic phenomena in filamentous fungi: useful paradigms or repeatinduced confusion? Trends Genet. 13:296-301.

38. Sutton, B. C. 1992. The genus Glomerella and its anamorph Colletotrichum. Pages 1-26 in: Colletotrichum: Biology, Pathology and Control. CAB International, Wallingford, UK.

39. Thomma, B. P. H. J., Tadesse, Y. S. H., Jacobs, M., and Broekaert, W. F. 1999. Disturbed correlation between fungal biomass and betaglucuronidase activity in infections of Arabidopsis thaliana with transgenic Alternaria brassicola. Plant Sci. 148:31-36.

40. Tsegaye, Y., Shintani, D. K., and DellaPenna, D. 2002. Overexpression of the enzyme phydroxyphenolpyruvate dioxygenase in Arabidopsis and its relation to tocopherol biosynthesis. Plant Physiol. Biochem. 40:913-920.

41. Vandemark, G. J., and Barker, B. M. 2003. Quantifying Phytophthora medicaginis in susceptible and resistant alfalfa with a real-time fluorescent PCR assay. Phytopathol. Z 151:577-583.

42. Watson, A. K., Gressel, J., Sharon, A., and Dinoor, A. 2000. Colletotrichum strains for weed control. Pages 245-265 in: Colletotrichum: Host Specificity, Pathology, and Host-Pathogen Interaction. American Phytopathological Society Press, St. Paul, MN.

43. White, T. J., Bruns, T., Lee, S., and Taylor, J. 1990. Amplification and direct sequencing of fungal ribosomal RNA genes for phylogenetics. In: PCR Protocols: A Guide to Methods and Applications. M. A. Innis, D. H. Gelfand, J. S. Sninsky, and T. J. White, eds. Academic Press, Inc., San Diego, CA.

44. Wilson, I. G. 1997. Inhibition and facilitation of nucleic acid amplification. Appl. Environ. Microbiol. 63:3741-3751.

45. Winton, L. M., Stone, J. K., Watrud, L. S., and Hansen, E. M. 2002. Simultaneous one-tube quantification of host and pathogen DNA with real-time polymerase chain reaction. Phytopathology 92:112-116.

46. Wymore, L. A., Poirier, C., Watson, A. K., and Gotlieb, A. R. 1988. Colletotrichum coccodes, a potential bioherbicide for control of velvetleaf (Abutilon theophrasti). Plant Dis. 72:534-538. 